\title{
Yanıklarda Akut Dönem ve Hemşirelik Bakımı
}

\author{
Acute Period in Burns and Nursing Care
}

\author{
Aylin AYDIN SAYILAN ${ }^{\mathrm{a}}$, Ezgi SEYHAN AK ${ }^{\mathrm{b}}$, Nevin KANAN ${ }^{\mathrm{c}}$
}

ÖZ Yanık; özel, yoğun ve uzun süreli tedavi gerektiren cerrahi bir travmadır. Yanıkta akut dönem ise, yanığın olumsuz etkilerine karşı organizmayı hazırlıklı hale getirmek amacıyla, oluşan bir dizi reaksiyonlar bütünü olarak tanımlanmaktadır. Yanık hastasında, cilt bariyeri bozulduğu için ciddi sıvı, elektrolit, protein, mineral kayıpları olmakta; yoğun katabolik durum, infeksiyonlar ve yara iyileşmesi sonucunda artan gereksinimler nedeni ile protein, enerji ve mikrobesin ögesi eksiklikleri gelişebilmektedir. Bu nedenle, yanığın akut dönem tedavi ve bakımında; yara bakımı, infeksiyon kontrolü, ağıı yönetimi, fizik tedavi ve beslenme önemli rol oynamaktadır. Sağlık bakım ekibi içinde yer alan hemşirelerin yanıklı hastanın bakımındaki rol ve sorumlulukları büyüktür. Bu derlemede; yanıklarda akut dönem ve hemşirelik bakımına yer verilmiştir.

Anahtar sözcükler: Yanık, akut dönem, hemşirelik bakımı

ABSTRACT Burn is a surgical trauma that requires special, intensive and long-term treatment. The acute phase of ambustion is defined as a set of reactions that are occurred in order to prepare the organism against the adverse effects of the burn. In an ambustion patient, there is serious fluid, electrolyte, protein, mineral loss as a result of the deterioraton of the skin barrier. Protein, energy and micronutrient deficiencies may develop due to increased needs as a result of high catabolic status, infections and wound healing. Therefore, wound care, infection control, pain management, physical therapy and nutrition play important roles in the acute phase of treatment and care. The roles and responsibilities of the nurses in the health care team are important in the care of the burn patient. In this review, acute period in burns and nursing care were included.

Keywords: Burn, acute period, nursing care.

\section{Giriş}

Yanık; özel, yoğun ve uzun süreli tedavi gerektiren cerrahi bir travmadır. Akut dönem, yanığın olumsuz etkilerine karşı organizmayı hazırlıklı hale getirmek amacıyla, oluşan bir dizi reaksiyonlar bütünüdür. Yanık hastasında, cilt bariyeri bozulduğu için ciddi sıvı, elektrolit, protein, mineral kayıpları olmakta; yoğun katabolik durum, infeksiyonlar ve yara iyileşmesi sonucunda artan gereksinimler nedeni ile protein, enerji ve mikrobesin ögesi eksiklikleri gelişebilmektedir. $\mathrm{Bu}$ aşamada hemşirenin, akut dönemdeki gereksinimleri bilmesi ve buna yönelik acil bakım vermesi, hastanın yaşamını sürdürebilmesi açısından büyük önem taşımaktadır $(1,2)$.
Yanıkta Akut DönemYanıkta, ilk 24-48 saat erken ya da akut dönem, daha sonraki dönem ise hipermetabolik ya da geç dönem olarak adland1rılmaktadır. Akut dönem, yanık alanının tamamen cilt dokusuyla kaplanıp, yara iyileşme süreci başladığında sona erer. Bu süreç, haftalarca ve ya aylarca sürebilmektedir (1-3).

\section{Fizyopatoloji}

Yanık yarasında, cilt bariyerinin ortadan kalkmas1 ile birlikte 1sı ve sıvı kaybına yol açan fizyopatolojik değişimler oluşur. Büyük yanıklarda lokal ve sistemik mediyatörlerin salınımı gerçekleşmekte, kapiller geçirgenlikte artış ve ekstrasellüler sıvının hareketi sonucu hastada yaygın ödem

Geliş Tarihi/Received:11-01-2018/ Kabul Tarihi/Accepted:19-07-2018

aYard. Doç. Dr. Kırklareli Üniversitesi Sağlık Yüksekokulu Hemşirelik Bölümü, , e-mail: aylinay_85@msn.com, ORCID ID: /0000-0003-0576-8732

${ }^{\mathrm{b}}$ Dr. İstanbul Üniversitesi Florence Nightingale Hemşirelik Fakültesi, Cerrahi Hastalıkları Hemşireliği; ORCID: 0000- 0002-3679-539X

'Prof. Dr. İstanbul Üniversitesi Florence Nightingale Hemşirelik Fakültesi, Cerrahi Hastalıkları Hemşireliği AD.

Sorumlu yazar /Correspondence: Aylin Aydın Sayılan, e-mail: aylinay_85@msn.com 
oluşmaktadır. Akut dönemde gelişen bu ödem, hem tam kalınlıklı hem de kısmi kalınlıklı yanıklarda, acil döneme göre daha belirgin olmaktadır. Yine, bu dönemde hasta uyanık ve durumun farkında olabildiğinden hemşirenin, hastaya psikososyal destek vermesi büyük önem taşımaktadır (1). İyileşme sürecinde, yara çevresinde lökosit birikimi ve fagositoz görülmekte, nekrotik doku sertleşmeye başlamaktadır. Fibroblastlar yara iyileşme sürecinde yer alan bir sitokin olup, kollajen oluşumunda rol oynamaktadır. Bunun sonucunda da granülasyon dokusu oluşumu gerçekleşmektedir. Kısmi kalınlıktaki yanık yaraları, infeksiyondan korunur ve yeterli nem sağlanırsa, kenarlardan ve dermal tabakadan iyileşme başlar. Bununla birlikte, yanık yarasının büyük ve derin olduğu durumlarda, eksizyon ve greftlemeden yararlanılmaktadır. Literatürde, eksizyon ve greftlemenin erken dönemde yapılmasının yara iyileşmesi ve hastanede kalış süresini kısalttığı, greftin 6 hafta sonrasında sağlam ve elastik bir iyileşme sağladığı bildirilmektedir $(1,4)$.

\section{Klinik Belirti ve Bulgular}

Özellikle kısmi yanıklarda, yaralanmadan hemen sonra skar dokusunun oluşumu görülmektedir. Skar dokusunun kaldırılmasıyla, yara kenarlarında reepitelizasyon başlamakta, bu durum kırmızı veya pembe yara dokusu olarak gözlenmektedir. 10-21 gün arasında, cerrahi girişim olmaksızın, epitel tomurcuklar ortaya çıkar ve yara kendiliğinden iyileşmektedir. Tam kalınlıkta yanıklarda skar dokusunun kenar boşluklarına ayrılması daha uzun sürer. $\mathrm{Bu}$ nedenle, tam kalınlıktaki yanıklar, cerrahi debridman ve yara iyileşmesi için cilt grefti gerektirmektedir (1).

\section{Tedavi ve Bakım}

Yanıkta tedavi ve bakım girişimleri, yanığın şiddetine ve hastanın bulunduğu evreye göre değişmektedir. Yanıkta tedavi ve bakım; acil, akut ve rehabilitasyon olmak üzere üç dönemde gerçekleştirmektedir (Tablo 1) (5).

Akut dönemde yanık bakımı, yaralanmadan sonra ilk 24-48 saatte başlamaktadır. Akut dönemdeki girişim hedefleri; infeksiyon olmaması, skar izinin minumum olmas1, maksimum işlev, konforun sağlanması, yeterli beslenme desteği, sıvı elektrolit asit-baz dengesinin sürdürülmesidir (6-8).

\section{Yara Bakımı}

Yanıklı hastada bakım sonuçları, günlük yara bakımı, izlemi, eksizyonu ve yaranın kapanması ile infeksiyonun tedavisi ve önlenmesine bağlidır.

\section{Yara bakımının hedefleri;}

$\checkmark$ Mikrobiyal kolonizasyon kontrolü ve yara infeksiyonunu önlemek.

$\checkmark$ Yaranın derinleşmesini önlemek.

$\checkmark$ Mümkün olan en kısa sürede yaranın kapanmasını sağlamak.

$\checkmark$ İyileşen cildin fonksiyonunu arttırmaktır $(5,6)$.

Yaranın Debride Edilmesi: Yanık dokusu, fagositozu uyaran kimyasal mediatörlerin salınımını serbest birakır. Nekrotik doku fagositik harekete karşın, iyileşmeyi geciktirir ve inflamasyon süresini uzatır. İnfeksiyonu önlemek ve iyileşmeyi hızlandırmak için yara her gün temizlenir ve debride edilir. Yara temizliği duş sedyesi, duş koltuğu ya da yatak başı bakım kullanılarak yapılır. Debridman ya da ölü dokunun çıkarılması, mekanik, kimyasal, cerrahi ya da bu üç yöntemin kullanılması ile gerçekleştirilir. Mekanik debridmanda ölü dokuyu gevşetmek için manuel olarak makas, forseps veya 1slak-nemli ince gözenekli gazlı bez sargiları kullanılabilir. Kimyasal debridman, nekrotik dokuyu uzaklaştıran bir proteolitik enzimatik debridman maddesinin kullanılmasıdır. Cerrahi debridman ise, tam veya kısmi kalınlıktaki yanıkların kesilerek çıkarılmasıdır. $\mathrm{Bu}$ yöntemden sonra bir cilt grefti uygulanır $(8,9)$.

Tam kalınlıkta yanık oluştuğunda koagüle olan dokulara ek olarak gelişen yoğun ödem ve artan doku basincı venöz ve arteriyel dolaşımı engelleyerek, derinde yer alan dokuların iskemisine neden olur. Bu tür yanıkların yaygın olduğu yerler, ekstremite, gövde ve gögüus bölgesidir. Yanık, göğüs ve gövdede meydana gelirse gögüsün genişlemesi kısıtlanacağı için solunum yetmezliği gelişebilir. Bu basıncı ortadan 
Tablo 1. Yanık Bakımının Dönemleri

\begin{tabular}{|c|c|c|}
\hline Evre & Süresi & Girişimler \\
\hline I (Acil) & $\begin{array}{l}\text { Yaralanmanın başlangıcından } \\
\text { diüreze kadar }\end{array}$ & $\begin{array}{l}\text { - } \text { Isı kaynağı hastadan uzaklaştırılır. } \\
\text { - } \quad \text { Illk yardıma başlanır. } \\
\text { - } \quad \text { Yanığın derecesi değerlendirilir. } \\
\text { - Hipotermi önlenir. } \\
\text { - Hasta şok belirtileri açısından izlenir. } \\
\text { - } \quad \text { Entübasyon gereksinimi belirlenir. } \\
\text { - Intravenöz tedavi gereksinimi belirlenir. } \\
\text { - Siv1 resüsitasyon protokolü izlenir. } \\
\text { - Hasta öyküsü elde edilir. } \\
\quad \text { Hasta üçüncü basamak sağlık hizmetlerine nakil } \\
\quad \text { edilir. }\end{array}$ \\
\hline II (Akut) & $\begin{array}{l}\text { Diürez başlangıcından yara } \\
\text { kapanışının tamamlanmasına } \\
\text { kadar }\end{array}$ & $\begin{array}{l}\text { - Hidroterapiye başlanır. } \\
\text { - } \quad \text { Yanı̆̆ın eksizyon gereksinimi değerlendirilir. } \\
\text { - İnfeksiyonun yayılması önlenir. } \\
\text { - } \quad \text { Yara bakımı yapılır. } \\
\text { - } \text { Beslenme desteğine başlanır. } \\
\text { - } \quad \text { Yanık yarası grefti pansuman materyalleriyle } \\
\text { kapatılır. } \\
\text { - Fizik tedaviye başlanır. } \\
\text { - Ağrı yönetimi }\end{array}$ \\
\hline $\begin{array}{l}\text { III } \\
\text { (Rehabilitasyon) }\end{array}$ & $\begin{array}{l}\text { Yara kapanışından optimum } \\
\text { bedensel ve psiko-sosyal } \\
\text { fonksiyon seviyesine geri } \\
\text { dönene kadar }\end{array}$ & $\begin{array}{l}\text { - } \quad \text { Skar oluşumu önlenir. } \\
\text { - } \quad \text { Fizik tedaviye devam edilir. } \\
\text { - } \quad \text { Psikososyal, kültürel, spiritüel gereksinimleri } \\
\text { belirlenir. } \\
\text { - } \quad \text { Evde bakım yönetimi değerlendirilir. }\end{array}$ \\
\hline
\end{tabular}

kaldırmak için eskaratomi yapılır. Fizik incelemede tahta sertliği hissinin alınması ve esnekliğin kaybı eskarotomi için karar vermeye yardimc1 olur.

Eskarotomi yapılarak derin fasyaları içerecek biçimde bistüri ile ekstremitelerin yan ve orta kenarlarından kesilir. Eskarotominin zamanında yapılırsa organ ve yaşam kurtarıcı olmasına karşın, kanama ve infeksiyon gibi komplikasyonları vardır $(5,10)$.

Yara Pansumanı: Yanık alanı temizlendikten sonra pansuman ve topikal tedavi uygulanır. Pansuman ve topikal ajanın tipi, yaralanmanın derecesine, derinliğine ve hekimin tercihine bağlıdır. Pansumanlar açık, kapal1, biyolojik, sentetik ve bunların kombinasyonundan oluşabilir. Açık yöntemde pansuman olmadan topikal madde kullan1lırken, kapalı yöntemde yaranın üzerine nemli bir yara ortamı sağlayan oklüsif (kapayıcı) pansuman uygulanır.

Pansuman için genel ilkeler aşağldaki gibidir:

$\checkmark$ Hareketi kolaylaştırmak için pansumanın hacmi sinırlanır.

$\checkmark$ Cilt yüzeyleri doğrudan birbiriyle temas ettirilmez.

$\checkmark$ Pansuman yaranın büyüklüğüne, emilimine, debridmanın tipine göre yapilır. 
$\checkmark$ Distalden proksimale venöz dönüşü arttırmak için ekstremiteler sarılır.

$\checkmark$ Pansumanların çok sıkı olmamasına dikkat edilir. Periferal nabızlar sık olarak izlenir.

$\checkmark$ Etkilenen ekstremite yükseltilir.

Biyolojik pansumanda, canlı ya da ölü insan veya hayvan dokuları yaygin olarak kullanılır. Biyolojik ve sentetik pansumanlar temiz kısmi ya da tam kalınlıklı yaralarda geçici yara örtüsü olarak kullanılır. Biyolojik pansumanlar yara iyileşmesi ve epitelizasyonu arttırırlar, bununla birlikte ağrıyı azaltır ve antibakteriyel bir etkileri vardır. Literatürde biyolojik pansumanların hastalar tarafindan iyi bir şekilde tolere edildiği, hastaların büyük çoğunluğunda pansuman değişimi süresince minimal ağrı gözlendiği bildirilmiştir. Biyolojik materyaller; Allogrefler (Homogref), Xenogrefler, Otogrefler olarak siniflandirılır $(11,12)$.

Homogreft ya da allogreft, kadavradan elde edilen insan derisidir. Dondurulmuş ürünlerin uzun süreli depolanması için yöntemlerin geliştirilmesi, canlı derinin pansuman için kullanım oranını arttırmıştır. $\mathrm{Bu}$ greftler, yanık desenine kesilen şeritler halinde üretilir ve steril teknik kullanılarak uygulanır. Normal koşullar altında bir homogreft, uygulamayı izleyen 14 ile 21 gün boyunca etkili bir geçici kapatma sağlar $(5,8,10,13)$.

Heterogreft ya da xenogreft, genellikle hayvan derisinden (özellikle domuz, sığır) elde edilir. Xenogrefler çoğunlukla yüzeysel parsiyel yanıklarda ve donör alanlarının geçici olarak kapatılması amacıyla kullanılır. Uygulandıkları bölgeye kolayca ve sıkıca yapışırlar; ancak uygulandıktan sonra heterogreftte erken yumuşama meydana gelir ve yaradan enzimatik hareketle greft eriyebilir. $\mathrm{Bu}$ nedenle heterogreft pansuman değişimi gereklidir. Gümüş nitrat (\%5'lik) minimal emilim ve toksisiteyle geniş bir antimikrobiyal etkiye sahip olduğu için infeksiyonları önlemede kullanılmaktadır $(5,8,10,13)$.

Otogrefler, aynı bireyde bir bölgeden başka bir bölgeye nakil edilen greflerdir. Yara ve yanıkların kalıcı olarak kapatılmasında kullanılan en uygun yöntemdir. Ancak geniş yanıklarda donör alan yetersizliği bir takım cilt yerine geçebilecek materyallerin geliştirilmesine neden olmuştur $(5,8,10,13)$.

\section{Infeksiyon Kontrol Önlemleri}

Major yanığı olan hastalarda sistemik infeksiyon ölüme neden olmaktadır. Stafilakok ve streptekok gibi gram pozitif mikroorganizmalar yanık sonrası ilk bir hafta içinde kolonize olurlar. Gram negatif enterik organizmalar ise genellikle daha uzun süreli hastanede kalış durumlarında görülür. İnfeksiyon tanısı yara yerinden alınan biyopsi ile konur. Yanık yüzeyinde infeksiyon oluşumunu önlemek için protokole uygun olarak antimikrobiyal tedavi uygulanır. Topikal antibiyotik seçimi, yanığın genişliğine, bakteriyel organizmaların varlığına, tedavinin açık ya da kapalı uygulanmasina ve hastanın yanıtına göre değişir. Antimikrobiyal tedaviye karşın, majör yanığ 1 olan hasta sepsis ve septik şok yönünden büyük risk altındadır $(5,8,10)$.

Yanık yerinde infeksiyonun lokal belirtileri;

$\checkmark$ Yanık dokusunda döküntünün artması,

$\checkmark$ Yara kenarlarında ödem artışı,

$\checkmark$ Kısmi kalınlıklı yaradan tam kalınlıklı yaraya dönüşmesi,

$\checkmark$ Siyah ve kahverengi renk değişimleri,

Major yanığ 1 olan hastaya genellikle profilaktik antibiyotik uygulanır. Eksizyon ve otogref uygulanmasinın ameliyat öncesi ve sonras1 döneminde, sistemik antimikrobiyal tedavi tercih edilir. Ameliyat sonrası hastanın hemodinamik durumu normale döner dönmez (genellikle ilk 24 saat içinde) tedavi sonlandırılır. Hastanın immünizasyon durumu şüpheli ise, klostiridum tetani infeksiyo- 
nunu önlemek için akut fazın erken döneminde tetanoz toksoid uygulanır $(5,9)$.

Yanık ünitelerinde kültür ve sürveyans yöntemleri önemli yer tutmaktadır. Yanık yerinden haftada iki veya üç kez yara kültürü alınması; yarada kolonize olan mikroorganizmanın erken dönemde belirlenmesi; tedavi etkinliğinin izlenmesi, perioperatif antibiyotik tedavisinin yönlendirilmesi açısından gereklidir. Bununla birlikte yanığ olan hastanın izlem ve tedavisi sirasında standart izolasyon önlemlerine dikkat edilmesi gerekmektedir. Çoğul dirençli mikroorganizmalarla kontamine veya infekte yanık hastaların ortamı ve diğer hastaları kontamine etmemeleri için izolasyon önlemleri alınır $(9,10,14)$.

\section{Ăgrı Yönetimi}

Yanık hastasının ağrı kontrolünde en önemli nokta doğru zamanlamadır. Yanığı olan hastalarda ağrının giderilmesi, yaralanmadan hemen sonra başlayıp rehabilitasyon döneminin sonuna kadar mutlaka uygulanması gereken bir girişimdir. Yanık yarasının yanında, tedavi sirasında uygulanan pansuman, fizik tedavi ve mobilizasyon gibi işlemler de ağrı oluşturmaktadır $(5,14)$.

Akut dönemde opioidler, dinlenme sırasında ortaya çıkan ağrıyı azaltmak için uygulanır. Hasta stabilize olduktan sonra düşük doz özellikle intravenöz yoldan opioidler verilmektedir. Opioidler uygulandığı zaman antiemetikler gerekli olabilir. Yanık hastasında sik sik ağrı kontrolünün yapılması gerekmekte; ağrı kaynağına uygun analjezik veya sistemik opioid kullanımı tercih edilmektedir. Genellikle yoğun bakım ünitesinde tedavisi devam eden hastada, hasta kontrollü analjezi ağrıyla baş etmesinde önemli bir uygulamadır. Hemodinamik stabilite ve bozulmuş doku perfüzyonu geri gelene kadar oral, subkutan veya intramusküler uygulama yolundan kaçınılmalıdır. Ağrı yönetimi için diğer girişimler, gevşeme bantlarının kullanımı, hayal kurma, biyofeedback gibi farmakolojik olmayan yöntemleri içerir $(6,9,15)$.

\section{Fizik Tedavi}

Yanıklı hastalarda kontraktür sık görülen bir sorundur. Tedavi sırasında kontraktürleri önlemek için hastanın pozisyonu korunmalıdır. Fleksiyon, eklem ve ekstremitenin doğal dinlenme pozisyonu olduğu için fizik tedavi deformiteyi önleyen pozisyonları sürdürmeyi içerir. Ateller vücut bölümlerinin immobilizasyonunu sağlayarak eklemlerdeki kontraktürleri önler. Ateller, fizik tedavi uzmanı tarafindan eklemleri fonksiyonel pozisyonlarda tutmak için uygulanmalı ve uygun olup olmadığı kontrol edilmelidir. Yaralanmadan sonra mümkün olan en kısa sürede uygulanmaya başlanmalıdır. Uygulanan atellerin fizik tedavi programlarına göre çıkarılması önerilmektedir. Akut fazın erken dönemlerinde fizik tedavi terapisti tarafindan iki saatte bir aktif ve pasif ROM (Range of Motion) egzersizleri uygulanır. İdeal egzersiz programı hastaneye kabulde başlamalı ve yara iyileşinceye kadar devam etmelidir $(5,9,10)$.

\section{Beslenme}

Yanıklı hastada beslenme, metabolik gereksinimleri karşılamak, yara iyileşmesini hızlandırmak, infeksiyona karşı direnci arttırmak, protein kaybını azaltmak için oldukça önemlidir.

Yaralanmadan 6-12 saat sonra, hastanin duodenal ya da jejunal enteral beslenilmesi sonuçları iyileştirebilir. Karbonhidratlar yağlardan daha iyi enerji kaynağı olduğu için yanık sonrası beslenme içeriği $\% 82$ karbonhidrat, $\% 15$ protein, $\% 3$ oranında yağdan oluşmalıdır. Günlük protein gereksinimi en az 1.5-2 gr/kg'dır. Omega-6 yağ asitleri ile karşılaştırıldığında, omega-3 yağ asitleri, daha iyi bir inflamatuvar yanita neden olur. Multivitamin ve minarel desteği normal olmalidir.

Kollojen sentezi için diyette C vitamini, yara iyileşmesi ve epitelizasyon için 
A vitamini, yara iyileşmesi ve lenfatik fonksiyonlar için çinko, protein düzeyini arttırmak ve infeksiyon görülme sıklığını azaltmak için aminoasit glutamin desteği önerilir. Hasta ağızdan beslenebiliyorsa ancak besin alımı yetersiz ise gece enteral beslenme desteği uygulanabilir. Parenteral beslenme, infeksiyon riski olduğu için enteral beslenmeyi tolere edemeyen hastalarda tercih edilmelidir $(5,6,8)$.

\section{Akut Dönemde Görülen Olası Komplikasyonlar \\ Infeksiyon: Yanık sonucunda vücudun ilk} savunma yeri olan cilt yok edilir. Patojenler, genellikle yeterli fagositoz sağlanamadan çoğalmaya başlar. Sonucunda, yanık yarasında bakteri kolonizasyonu gelişir. Skar dokusu ile canlı doku birleşiminde bulunan bakteri sayısı $10^{5} / \mathrm{g}$ ve üstü seviyelerde olduğunda, yanık hastasında yara yerinde infeksiyon tanısı konur. İnfeksiyon varlığ1nda, lokal inflamasyon, hassasiyet ve yara yerinde iltihaplanma da görülebilir. $\mathrm{Bu}$ infeksiyonların yayılımının artması sonucunda, kısmi kalınlıklı yara tam kat yaraya dönüșebilir. İnvaziv yara infeksiyonlarında kültür sonucuna göre sistemik antibiyotik kullanımı gereklidir (16).

Yaraya geç ya da uygun olmayan girişimlerde bulunulması sebebiyle yanık yara sepsisi gelişebilmektedir. Sepsisin ilk belirtileri arsasında hipotermi veya hipertermi, kalp atım ve solunum sayısında artış, kan basıncında ve idrar miktarında azalma yer almaktadır. Daha sonra; iștahsızlık, bilinç bulanıklığ 1 , titreme, huzursuzluk gibi belirtiler de görülebilir. Sepsise neden olan organizma, siklikla gram negatif bakterilerdir (Psedömonas, Proteus vb.). Bu hastalar aynı zamanda septik şok için de risk altındadır. Literatüre göre yanık yara-sında, hastanede kalınan dönem içerisinde MRSA (Metisiline dirençli Stafilokokus aureus) oluşumu da sık gözlenebilmektedir (17).

Yanık sonrası sepsis gelişimine yönelik yapılan bir çalışmada, hastaların \%26'sında sepsis görüldüğü, ölüm oranının ise \%11.9 olduğu belirtilmektedir (18).

Yanık sonras1 hastada sepsisten şüpheleneliyorsa; zaman kaybetmeden, yara yeri, kan, idrar, balgam, orofarenks, perineal ve intravenöz girişimin uygulandığ 1 yerlerden kültür alınmalı, uygun antibiyotik tedavisi başlanmalıdır.

Kardiyovasküler ve Solunum Sistemi: Kalp yetmezliği, akciğer ödemi, disritmiler, venöz tromboembolizm, acil dönemde başlayıp, akut fazda da devam eden temel sorunlardır. Hasta kalp krizi veya solunum arresti nedeniyle kaybedilebilmektedir. Hastanın hemodinamik monitörizasyonu, kalp ve solunum sistemini destekleyici girişimler uygulanmalıdır (1).

Nörolojik Sistem: Yanık sonrası, solunum yolları etkilenmemişse ya da elektrik kaynaklı bir yanık değilse, hastada nörolojik açıdan bir belirti gözlenmez. Bununla birlikte, bazı hastalar söylenenleri anlamada güçlük yaşayabilir. İleri yaş hastalarda deliryum tablosu eşlik edebilir (19). Bu durum, birkaç haftaya kadar sürebilir. Psikiyatri ve geriatri alanlarından ortak konsültasyon, bu sorunun çözümünde yol göstericidir. Altta yatan elektrolit dengesizliği, stres, serebral ödem, sepsis, analjezik/antianksiyolitik ilaç kullanımı ve uyku bozukluğu gibi faktörler de irdelenmelidir (1).

Kas - İskelet Sistemi: Akut dönemde, kas iskelet sistemine ilişkin komplikasyonlar oldukça sık görülür. Yanık sonrası skar dokusu oluştuğundan, cilt elastikiyetini kaybeder. $\mathrm{Bu}$ nedenle ROM hareketlerini yapmada güçlük ve kontraktür gelişimi gibi olumsuzluklar gelişir. Ağrı nedeniyle, hasta fleksiyon pozisyonuna eğilimlidir (20). Bu dönemde, yanık yerinin gerginleştirilmesi, eklem hareketliliğinin sağlanması, kontraktür gelişimini önlemede yararlı olabilir (21). 
Gastrointestinal Sistem: Gastrointestinal sisteme ilişkin, sepsis kaynaklı paralitik ileus; enteral beslenme veya antibiyotik kullanımına bağlı diyare; mobilizasyon, düşük lifli diyet, opioid analjeziklerin yan etkisi sonucunda konstipasyon görülmektedir. Yanık sonras1, gastrointestinal sisteme olan kan akışında azalma ile karakterize Curling's ülseri bu dönemde de devam etmektedir. Tedavisinde hastanın mümkün olduğunca erken dönemde beslenmesi, antiasit (Ranitidine $\mathrm{vb}$ ) ve proton pompa inhibitörleri (Esomeprazole vb.) kullanımı büyük önem taşır. Major yanığı olan hastaların, bu dönemde dışkılarında gizli kan görülebilir (1).

Endokrin Sistem: Yanık sonrası erken dönemde metabolik hız azalır; resüsitasyon ile katabolik veya hipermetabolik bir tablo gelişir. Katekolamin, glukagon ve kortizol değerleri artarken insülin ve triiyodotironin değerleri azalır (22). Kandaki glikoz seviyesi artar, sonucunda hiperglisemi gelişir. $\mathrm{Bu}$ durumda hastanın beslenmesi sinırlandırılmaz, intravenöz insülin tedavisi başlanır. $\mathrm{Bu}$ nedenle, kan glikozu, glukometre ile izlenmeli, hastanın stres durumu da değerlendirilmelidir (23).

\section{Akut Dönemde Hemşirelik Bakımı Tanı, Beklenen Sonuç ve Girişimler} Major yanıklar tüm vücut sistemlerini etkileyerek sosyal, ekonomik, psikolojik ve spirütüel sorunların gelişmesine neden olmaktadır.

Hemşirelik Tanısı: Cilt bütünlügünde bozulma

Amaç/Beklenen Sonuçlar: Dolaşım bozukluğu ve ödem olmaması.

\section{Hemşirelik Girişimleri}

Yanıkta hemşirelik bakımı, yaralanmanın değerlendirilmesi, temizlenmesi ve infeksiyon kontrolüne odaklanır. $\checkmark$ Yanığın görünümü, miktarı, drenaj tipi, vücut sıcaklığı, lökosit sayısı yakından izlenir.

$\checkmark$ Debridman ve hidroterapiyi içeren günlük yara bakımı yapılır. Ortamın nemli olması sağlanır.

$\checkmark$ Order edilen topikal antimikrobiyal ajanlar uygulanır.

$\checkmark$ Vücudun hassas alanlarının özel cilt bakımı yapılır.

$\checkmark$ Temiz yanıklarda (ör: göz) normal tuzlu su ya da steril su kullanilır. Göz kapağında kontraktür gelişirse, korneada yırtılmayı önlemek için damla ya da merhem uygulanır.

$\checkmark$ Dudaktaki yanıklarda dudaklar tuzlu su ile ıslatılmış petle silinir. Order edilen antibiyotikli merhemler uygulanır. Ağız sık olarak değerlendirilir ve düzenli olarak ağız bakımı uygulanır.

$\checkmark$ Aşırı basınç oluşumunu önlemek için nazogastrik ve nazotrakeal tüplerin yeri değiştirilir.

$\checkmark$ Kulaklar pansumanla kapatılmaz. Kulaklara olan basıncı azaltmak için köpük pedler kullanılır.

$\checkmark$ Pansumanlar değiştirilir. Açık yöntem kullanıldığında steril yöntem kullanılır. Kapalı yöntem distalden proksimale uygulanır.

$\checkmark$ Cilt grefti yerleştirilmiş eksremiteler kalp seviyesinden yukarida tutulur.

$\checkmark$ Cilt greft alanlarının 3-5 gün hareket-siz olması sağlanır.

Hemşirelik Tanısı: Sıvı Volüm Eksikliği Amaç/ Beklenen Sonuçlar: Yeterli dolaş1min sağlanması

\section{Hemşirelik Girişimleri}

$\checkmark$ Yaralanmadan sonra aşırı sıvı kaybı olur ve 2-5 gün devam eder. $\mathrm{Bu}$ süreçte hemşirelik bakımı, sıvı kaybının onarilması ve hemodinamik parametrelerin sürekli değerlendirilmesini içerir.

$\checkmark$ Hastanın yaşam bulguları sik olarak değerlendirilir. Nabızda zayıflık, kan 
basincinda azalma, solunum hizında artma gibi belirtiler kayıt edilir.

$\checkmark$ Order edilen IV sivilar uygulanır.

$\checkmark$ Saatlik aldığı-çıkardığı izlemi yapılır. İdrar çıkışı saatlik 50 cc'nin altında ise rapor edilir.

$\checkmark$ Günlük kilo izlemi yapılır.

Hemşirelik Tanısı: İnfeksiyon riski

Amaç/ Beklenen Sonuçlar: İnfeksiyon belirtilerinin gözlenmemesi

\section{Hemşirelik Girișimleri}

$\checkmark$ Vücut sicaklığı 1-2 saatte bir ölçülür ve kayıt edilir. Lökosit sayısı izlenir.

$\checkmark$ Tetanoz immünizasyon durumu belirlenir.

$\checkmark$ Asepsiye dikkat edilir.

$\checkmark \quad$ Ateş, idrarda bakteri, dizüri, varlığ değerlendirilir.

Hemşirelik Tanısı: Fiziksel aktivitede bozulma

Amaç/ Beklenen Sonuçlar: Kontraktür olmadan mümkün olan hareket düzeyinin sağlanmas1

\section{Hemşirelik Girişimleri}

$\checkmark \quad 2$ saatte bir aktif-pasif ROM egzersizleri uygulanır. Hastanın durumu stabil ise ayağa kaldırılır.

$\checkmark$ Order edilen ateller uygulanabilir. Hastanın pozisyonu saat başı değiştirilir.

$\checkmark$ Ekstremitelerin aynı hizada olması sağlanır.

Hemşirelik Tanısı: Beden gereksiniminden az beslenme

Amaç/ Beklenen Sonuçlar: Hastanın kilosunun normal sınırlar içinde olması

\section{Hemşirelik Girişimleri}

$\checkmark$ Nazogastrik ve nazointestinal tüpün yerleşimi sağlanır.

$\checkmark$ Order edilen enteral/parenteral beslenme desteği sağlanır. Beslenme intoleransı belirtileri varsa rapor edilir. Özellikle total vücut alanının \%15-20'sinden fazlası yan1k olan hastalarda erken ve yoğun enteral beslenme önerilmektedir. $\checkmark$ Hastanın günlük kilo izlemi yapılır.

$\checkmark$ Yanıklı hastalarda total kalorinin \%20'sinin yağlardan oluşması sağlanır.

$\checkmark$ Anabolik sürecin hızlanması için beslenme desteği, beslenme adjuvanları ve kas aktivitesi arttırılmalıdır.

$\checkmark$ Metabolik gereksinimi arttırıcı etkisinden dolayı, 1sı kaybını azaltıc1 önlemler alınır.

Hemşirelik Tanısı: Akut ağrı

Amaç/ Beklenen Sonuçlar: Hastanın ağrı düzeyin hafiflemesi

Hemşirelik Girişimleri

$\checkmark \quad$ Ağrı düzeyi değerlendirilir.

$\checkmark$ Hasta için hasta kontrollü analjezinin uygun olup olmadı̆̆ 1 belirlenir. Order edilen narkotik analjezikler uygulanır.

$\checkmark$ Hastaya yapılan girişimler ile ilgili bilgi verilir. Ağrılı girişimlere hazır olan hastanın stres düzeyi azalır ve ağr1 yönetimi daha iyidir.

$\checkmark$ Ağrı tedavisi için narkotik olan ağrı kontrolü tercih edilir.

\section{Değerlendirme}

Yara iyileşmesi, sıv1-elektrolit durumu, havayolu açıklığı, infeksiyon yokluğu, yeterli beslenme, ağrının azalması, komplikasyon gelişmemesi ile ilgili veriler toplanarak hemşirelik bakımının etkinliği değerlendirilir.

\section{Kaynaklar}

1. Knighton JA. Burns. Medical surgical nursing assessment and management of clinical problems 8th ed. International Edition Inc; 2010.p.486-488.

2. Korkmaz HI, Krijnen PAJ, Ulrich MMW, de Jong E, van Zuijlen PPM, Niessen HWM. The role of complement in the acute phase response after burns. Burns 2017; 43: 1390-1399.

3. Kuyumcu M, Şen H, Özkan S. Anesthesia in burn injury patients. TAF Preventive Medicine Bulletin 2011; 10(3): 351-360.

4. Greenwood JE. The evolution of acute burn care - retiring the split skin graft. 
Annals of the Royal College of Surgeons of England 2017;1-7.

5. Lemone P, Burke K, Bauldoff G, Gubrud $P$ (Eds.). Nursing care of patients with burns. In:Medical surgical nursing clinical reasoning in patient care 6th ed. New Jersey: Pearson Education Inc; 2015.p.432-450.

6. Connolly S. Clinical practice guidelines: burn patient management. Clinical Guidelines. NSW: Agency for Clinical Innovation 2011.

7. Burke KM, Mohn Brown EL, Eby L. Caring for clients with burns. In: Medical Surgical Nusing Care 3th ed. Pearson education, Inc; 2011. p.1160-1173.

8. Bolek Trofino R. Nursing care of patients with burns. In:Understanding Medical Surgical Nursing. Williams LS, Hopper PD, eds. 5 th ed. F.A Davis Company Philedelphia; 2015. p.1320-1336.

9. Kanan N. Yanıkta hemşirelik bakımı. Aksoy G, Kanan N, Akyolcu N, editör. Cerrahi Hemşireliği I. İstanbul: Nobel Tıp Kitabevleri; 2012.p. 115-152.

10. Smeltzer SC, Bare BG, Hinkle JL, Cheever KH.Management of patients with burn injury. In: Brunner \& Suddarth's Textbook of Medical Surgical Nursing. 11th ed. Lippincot Williams\&Wilkins; 2008.p. 1994-2037.

11. Koyutürk A, Demiray Soyaslan D. Yara ve Yanık Tedavisinde Kullanılan Örtüler. Mehmet Akif Ersoy Üniversitesi Fen Bilimleri Enstitüsü Dergisi Özel Sayı 2016; 1:58-65.

12. Shores JT, Gabriel A, Gupta S. Skin substitutes and alternatives: a review. Adv Skin Wound Care 2007; 20(9):493-508.

13. Altan S, Oğurtan Z. Termal yanıklarda pansuman uygulamaları. Dicle Üniv Vet Fak Derg. 2016; 2(11):118-126.

14. Yorganc1 K, Geyik SG. Ciddi yanık hastasının izlem ve tedavisi. Hacettepe Tip Dergisi 2007; 38:135-140.
15. Bittner EA, Shank E, Woodson L, Martyn JJ. Acute and perioperative care of the burn-injured patient. The Journal of the American Society of Anesthesiologists 2015; 122(2):448-464.

16. Duke JM, Randall SM, Wood FM, Boyd $\mathrm{JH}$, Fear MW. Burns and long-term infectious disease morbidity: A population-based study. Burns 2017;43(2):273-281.

17. Shek K, Patidar R, Kohja Z, Liu S, Gawaziuk JP, Gawthrop M, et al. Rate of contamination of hospital privacy curtains on a burns and plastic surgery ward: a cross-sectional study. The Journal of Hospital Infection 2017; 96(1):54-58.

18. Belba MK, Petrela EY, Belba A.G. Epidemiology and outcome analysis of sepsis and organ dysfunction/failure after burns. Burns 2017; 43:1335-347.

19. da Silva IR, Frontera JA. Neurologic complications of acute environmental injuries. Handbook of Clinical Neurology 2017; 141:685-704.

20. Porter C, Herndon DN, Sidossis LS, Børsheim E. The impact of severe burns on skeletal muscle mitochondrial function. Burns 2013; 39(6):1039-47.

21. Rrecaj S, Hysenaj $H$, Martinaj $M$, Murtezani A, Ibrahimi-Kacuri D, Haxhiu B, et al. Outcome of physical therapy and splinting in hand burns injury. Our last four years' experience. Materia Sociomedica 2015; 27(6):380-2.

22. Koltka K. Yanık Yaralanmaları: yanık derinliği, fizyopatolojisi ve yanık çeşitleri. Türk Yoğun Bakım Derneği Dergisi 2011; ISSN: 2146-6416.

23. Belba MK, Petrela E, Belba A, Mano V, Belba G. Statistical and clinical analysis of alterations in glucose values after burns. Annals of Burns Fire Disasters 2016; 29(3):163-171. 